\title{
GDSS Penentuan Lokasi Shelter Baru Transjogja Menggunakan Metode Brown-Gibson dan Borda
}

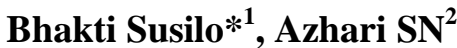 \\ ${ }^{1}$ Prodi S2/S3 Ilmu Komputer, FMIPAUGM, Yogyakarta \\ ${ }^{2}$ Jurusan Ilmu Komputer dan Elektronika, FMIPA UGM, Yogyakarta \\ e-mail: ${ }^{*}$ bhakti.susilo@gmail.com, ${ }^{2}$ arisn@ugm.ac.id
}

\begin{abstract}
Abstrak
Tujuan didirikannya armada bus Transjogja adalah untuk mengurai permasalahan kemacetan, polusi dan transportasi umum yang memadai. Untuk memberikan layanan yang terbaik, salah satu hal yang diusahakan adalah menempatkan shelter pada posisi yang tepat. Dinas perhubungan bekerja sama dengan instansi lain dalam pengumpulan aspirasi eksekutif untuk penentuan lokasi shelter baru.

Kombinasi Metode Brown-Gibson dan Borda memungkinkan digunakan untuk pemilihan lokasi secara kelompok. Metode ini digunakan untuk memilih alternatif lokasi berdasarkan ukuran preferensi tertentu (preference measurement) dengan mempertimbangkan faktor obyektif dan faktor subyektifnya. Faktor obyektif berupa efektifitas biaya yaitu jumlah total biaya yang dikeluarkan untuk satu alternatif lokasi. Faktor subyektif berupa pembobotan para pengambil keputusan terhadap kriteria-kriteria yang disyaratkan dalam penentuan lokasi shelter baru. Kriteria tersebut antara lain lahan, posisi, akses ruang, persaingan, transportasi dan keamanan. Dalam penilaian faktor subyektif menggunakan model AHP.

Hasil dari penelitian ini adalah GDSS dengan menggunakan metode Brown-Gibson dan borda terbukti dapat mengakomodasi preferensi dari banyak pembuat keputusan. Dengan keluaran berupa nilai preferensi lokasi dan rangking memudahkan DM menentukan pemilihan lokasi. Lokasi yang paling banyak memiliki rangking tertinggi lebih berpotensi sebagai lokasi shelter baru.
\end{abstract}

Kata kunci-Lokasi, Brown-Gibson, Borda

\section{Abstract}

The purpose of establishment of the Transjogja bus fleet is to solve the problems of congestion, pollution and adequate public transport. To provide the best service, one thing is to place the shelter afforded in the right position. Department of Communication, cooperate with other agencies in the collection of executive aspirations, for the determination of the location of the new shelter.

The combinations of Brown-Gibson and Borda methods, possible used for site selection as a group. This method is used to select an alternative location based on the size of a particular preference (preference measurement) taking into account the objective factors and subjective factors. Objective factor in the form of cost effectiveness is the total amount of expenses incurred for an alternative location. Subjective weighting factor of the decision makers of the criteria required in determining the location of the new shelter. These criteria include land, position, and access to space, competition, transportation and security. In the assessment of subjective factors is using the AHP model.

The result of this study is to GDSS using the Brown-Gibson method and Borda shown to accommodate the preferences of many decision makers. With the output of the value location preference and rankings, it facilitated DM to determine new location. Location that has the highest ranking is more potent as a location for a new shelter.

Keywords - Location, Brown-Gibson, Borda 


\section{PENDAHULUAN}

Dnetapan tempat henti yang tepat pada suatu lokasi merupakan bagian dari analisis jaringan rute dalam reformasi sistem dan manajemen angkutan umum berbasis Buy The Service. Dalam menentukan lokasi shelter yang tepat, Dinas Perhubungan dalam hal ini departemen Transjogja perlu menjaring aspirasi dari berbagai pihak terkait(stakeholders). Pihak yang terkait yang dimintai pendapatnya adalah eksekutif (instansi terkait di DIY antara lain: LLAJR, Dinas Pekerjaan Umum Bina Marga, Dinas Pemukiman dan Prasarana Wilayah Penataan Ruang, Serta PT Jogjatugu Trans), legislative, masyarakat umum, dan berbagai operator angkutan umum. Proses pengambilan keputusan tentang lokasi tempat henti /halte/shelter dilakukan secara bersama oleh kelompok eksekutif seperti disebutkan di atas.

Pentingnya keputusan secara bersama penentuan lokasi shelter ini karena, dalam penentuannya perlu mengacu pada studi yang ada seperti Tataran Tranportasi Wilayah (TATRAWIL) dan Rencana Umum Jaringan Transportasi Jalan (RUJTJ) oleh dishub dengan subdinas antaralain LLAJR dan TransJogja, Studi Jaringan Jalan DIY oleh Dinas PU. Pada proses penentuan lokasi shelter baru yang akan dibangun oleh Perhubungan subdinas Transjogja telah melakukan koordinasi secara fisik terhadap dinas lain. Dinas Perhubungan mengundang perwakilan dinas yang ditunjuk untuk ikut serta dalam meeting penentuan lokasi pada waktu dan tempat yang telah ditentukan. Untuk lebih mengefektifkan pengumpulan aspirasi eksekutif kepada suatu putusan lokasi shelter yang tepat diperlukan suatu model aplikasi yang dapat mengakomodasi preferensi dinas - dinas terkait terhadap alternatif lokasi yang ada. Sebuah aplikasi sistem pendukung keputusan kelompok / Group Decision Support Sistem dengan menggunakan metode Brown Gibson untuk pemilihan alternatif lokasi pada ranah Decision Maker dan Borda untuk metode voting kelompok. Metode Brown-Gibson digunakan untuk penilaian rating preferensi pada pemilihan lokasi karena metode ini menggabungkan penilaian Faktor Obyektif yang bernilai kuantitatif dan Faktor Subyektif yang bernilai kualitatif.

Beberapa penelitian yang telah dilakukan berkenaan dengan sistem pendukung keputusan kelompok dalam proses evaluasi antara lain:

Penelitian [1] mencoba mengetengahkan suatu metode pendekatan baru guna menganalisa dan mengevaluasi alternatif lokasi pabrik/industry yang ingin dipilih. Model pendekatan yang dikembangkan ini mencoba memilih alternatif lokasi berdasarkan ukuran preferensi tertentu dengan mempertimbangkan faktor obyektif dan faktor subyektifnya.

Penelitian [2] mengetahui bagaimana sistem yang dibuat mampu melakukan proses masukan yang diberikan, sehingga memberikan keluaran lokasi yang terbaik dengan melihat faktor subyektif dan faktor obyektif dari tiap - tiap lokasi yang diuji. Faktor subyektif yang digunakan adalah jauh dekatnya dari perumahan, asumsi masyarakat setempat dan penanganan limbah di calon lokasi, sedangkan faktor obyektif yang digunakan sebagai penilaiana dalam penentuan lokasi pabrik adalah biaya pajak, biaya distribusi, dan biaya karyawan.

Penelitian [3] untuk penilaian lokasi berdasarkan faktor subyektif dan faktor obyektif serta analisis sensitivitas. Hasil penelitian yang telah dilakukan terhadap ketiga alternatif lokasi cabang baru yang sebelumnya telah dilakukan oleh tim pengambil keputusan, maka dengan menggunakan analisis faktor, didapat lima faktor yang menjadi faktor subyektif dalam pemilihan lokasi cabang baru. Kelima faktor tersebut adalah luas, posisi, transportasi, keamanan dan akses. Oleh karena itu, penelitian terhadap faktor subyektif ini akan diprioritaskan.

Penelitian [4]tentang pemilihan lokasi garasi baru bus PO Akas jawa timur menggunakan metode Brown Gibson juga untuk menentukan lokasi garasi di Banyuwangi, Probolinggo, dan Bondowoso yang dianggap strategis dan optimal dilihat pada perolehan tertinggi dari faktor subyektif dan faktor obyektif serta Location Preference Measurement (LPM) untuk setiap alternatif lokasi yang ada. Penelitian ini bertujuan untuk mengetahui langsung kondisi obyek penelitian serta memperoleh langsung data - data tentang segala permasalahan yang berkaitan dengan obyek studi yang kemudian dianalisa lebih lanjut. Dari data analisa data yang dilakukan diperoleh hasil bahwa lokasi garasi di Banyuwangi, Probolinggo, dan Bondowoso memiliki nilai strategis yang tidak sama dan lokasi Probolinggo

IJCCS Vol. 6, No. 2, July 2012: 57 - 66 
memiliki nilai tertinggi dibandingkan dengan lokasi yang lainnya. Probolinggo dianggap sudah strategis sedangkan untuk lokasi Banyuwangi dan Bondowoso kurang strategis.

Penelitian [5]Menggunakan Metode Brown Gibson untuk penentuan lokasi b bimbingan belajar baru Lembaga Bimbingan Belajar Nurul Fikri di Jakarta mengidentifikasi 6 Subyektif faktor antara lain: Luas, Posisi, Transportasi, Keamanan, Akses dan Persaingan. Faktor subyektif yang sama akan penulis gunakan untuk kriteria penentuan lokasi shelter baru dengan beberapa subkriteria yang ditambahkan. Sedang Faktor Obyektif yang digunakan pada penelitian ini antara lain harga tanah, pajak, biaya pemeliharaan dan perbaikan, dan biaya lain lain.

Penelitian [6] tentang optimisasi penempatan perhentian bus (Halte) pada suatu jaringan jalan raya yang realistic yang bertujuan untuk meningkatkan layanan terhadap suatu rute transit. Dengan menggunakan Continuum Model Wirasinghe Goneim untuk mendapatkan penepatan bus stop yang optimum yang dipengaruhi factor walktime, operation time, dan ride time. Evaluasi dilakukan dengan membandingkan base case sekenario dari histori kumpulan halte bus terhadap suatu alternative dimana beberapa halte akan disisipkan atau dihilangkan dengan batasan fisik dari histori kumpulan halte halte yang ada. Pertimbangan penting dalam proses penggabungan perhentian bus adalah pemisahan pengaruh satu perhentian di dalam kumpulan perhentian, apakah pengaruh yang akan terjadi bila suatu perhentian disisipkan dan apa pengaruhnya pula apabila satu perhentian dihilangkan. Metode ini dirasa kurang tepat diterapkan pada penelitian karena hanya menganalisis dari factor obyektifnya saja, decision maker tunggal serta kriteria penentuan lokasi yang berbeda.

\section{METODE PENELITIAN}

\subsection{Deskripsi Sistem}

GDSS penentuan lokasi shelter baru bus transjogja merupakan sistem yang dipakai oleh para eksekutif yang dilibatkan dalam penentuan lokasi shelter baru bus Transjogja. Terdapat dua jenis user yang menggunakan sistem GDSS ini, yaitu: Admin dan para Pengambil Keputusan atau Decision Makers (DM). Admin berperan dalam manajemen user dan pelaporan hasil perhitungan. Para Pengambil Keputusan (DM) yang ikut terlibat dalam pengumpulan aspirasi eksekutif dalam penentuan lokasi shelter baru bus Transjogja adalah kepala Dinas dan Instansi terkait di DIY antara lain : Kepala Dinas Perhubungan Komunikasi dan Informatika(DisHubKomInfo) Yogyakarta, Kepala Divisi Transjogja, Kepala Dinas Pekerjaan Umum Energi dan Sumber Daya Mineral, Kepala Divisi Dinas Pengendalian Lalu Lintas dan Angkutan Jalan, Kepala Dinas Pemukiman dan Prasarana Wilayah, Direktur Jogja Tugu Trans.

\subsection{Rancangan Sistem GDSS}

GDSS penentuan lokasi shelter baru (Gambar 1) yang mempunyai input data dengan dua sumber yaitu internal dan eksternal. Data internal pengisiannya dilakukan oleh petugas yang ditunjuk sebagai administrator pada Dinas Perhubungan Komunikasi dan Informatika sebagai penanggungjawab system. Data eksternal didapat dari inputan para DM yang memberikan pembobotan pada kriteria, subkriteria, subsubkriteria. Basis data menggunakan DBMS MySQL, sedangkan basis modelnya menggunakan metode Brown Gibson dan Borda. Interface dengan user menggunakan aplikasi Web yang dibuat dengan bahasa pemerograman PHP. 


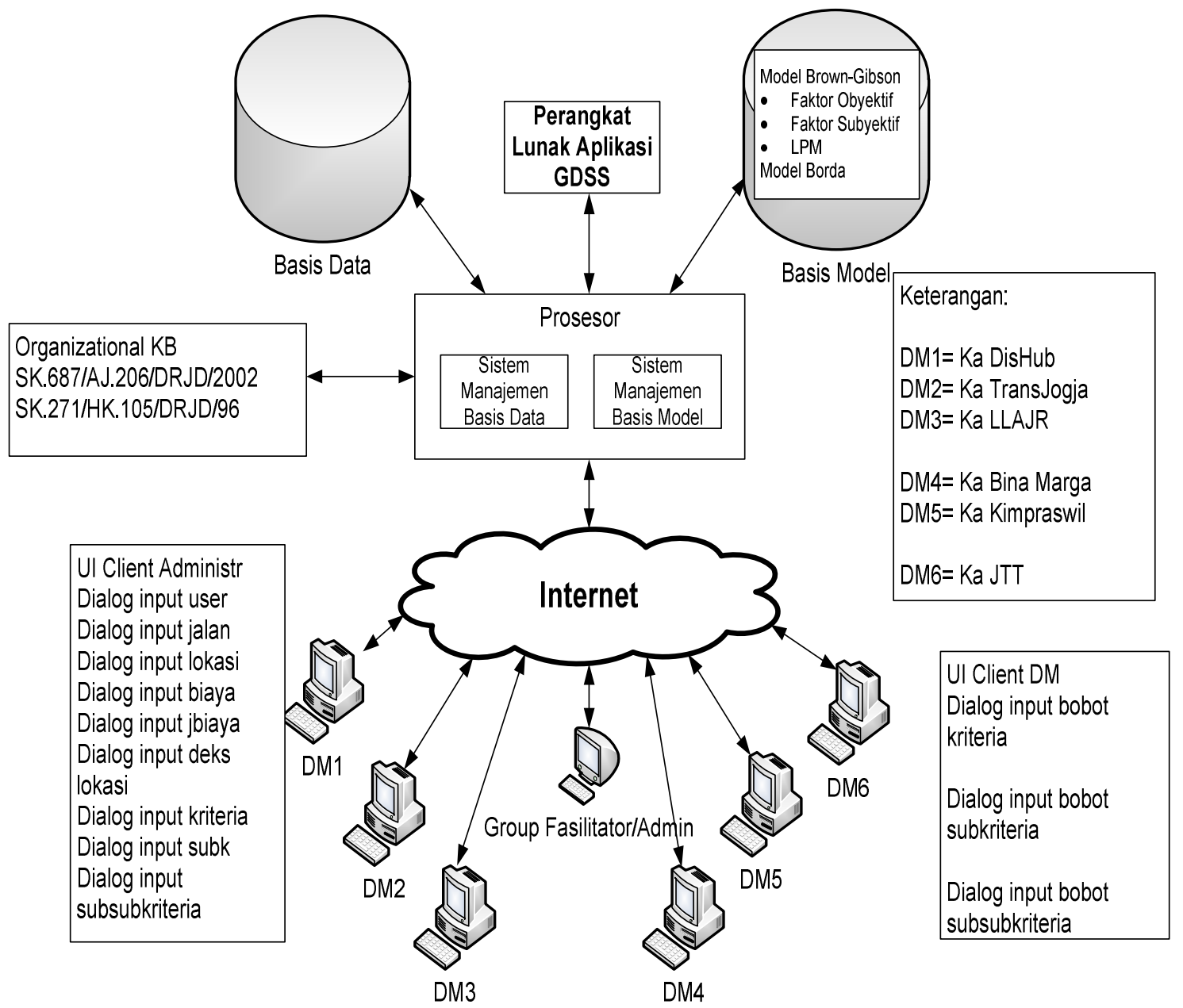

Gambar 1. Arsitektur GDSS penentuan lokasi sheter baru bus Transjogja

\subsection{Model Sistem Pendukung Keputusan}

Model Sistem Pendukung Keputusan secara khusus di gunakan dinas perhubungan untuk menentukan lokasi shelter baru transjojga, namun perlu mengetahui perferensi lembaga lain yang bersangkutan dalam pendirian shelter baru. Oleh karena itu untuk dukungan keputusan pada masing masing lembaga digunakan metode Brown Gibson yang didalamnya terdiri dari model penilaian obyektif, model penilaian subyektif dan model penilaian kombinasi antara faktor obyektif dan faktor subyektif yang akan menghasilkan LPM (location preference measurement). LPM ini akan menunjukan rangking untuk masing masing alternatif lokasi. Penilaian dari masing masing lembaga mungkin sama atau berbeda oleh karena itu diperlukan metode borda untuk pemberian rangking secara bersama dari masing - masing lembaga dengan rangking LPM yang berbeda. Dari hasil perhitungan borda akan muncul peringkat nilai dari alternative lokasi yang akan dipilih pada suatu ruas jalan.

\subsubsection{BrownGibson}

a. Faktor Obyektif

Mengacu kepada rumusan yang digunakan dalam metode Brown-Gibson pada [1], pengukuran performansi untuk setiap alternatif lokasi faktor obyektif dihitung berdasarkan estimasi biaya - biaya yang relevan dan masuk didalam perhitungan perhitungan total cost yaitu: biaya awal, biaya pemeliharaan, biaya pasang listrik, rekening listrik setahun, biaya tak terduga. Performansi faktor obyektif diperoleh dari persamaan: 
$O F=\left[c_{i} \Sigma \frac{1}{c_{i}}\right]^{-1}$

Dimana:

$\mathrm{OF}=$ Obyektif Faktor;

$\mathrm{Ci}=$ total cost

\section{b. Faktor Subyektif}

Penilaian faktor subyektif menggunakan metode AHP. Hirarki perangkingan lokasi pada AHP penilaian faktor subyektif terdiri dari 4 tingkat yaitu: (1)goal; (2)Kriteria; (3)Subkriteria; (4)Subsubkriteria; (5)alternatif lokasi. Hirarki perangkingan lokasi shelter baru oleh para DM ditunjukan pada Gambar 2.

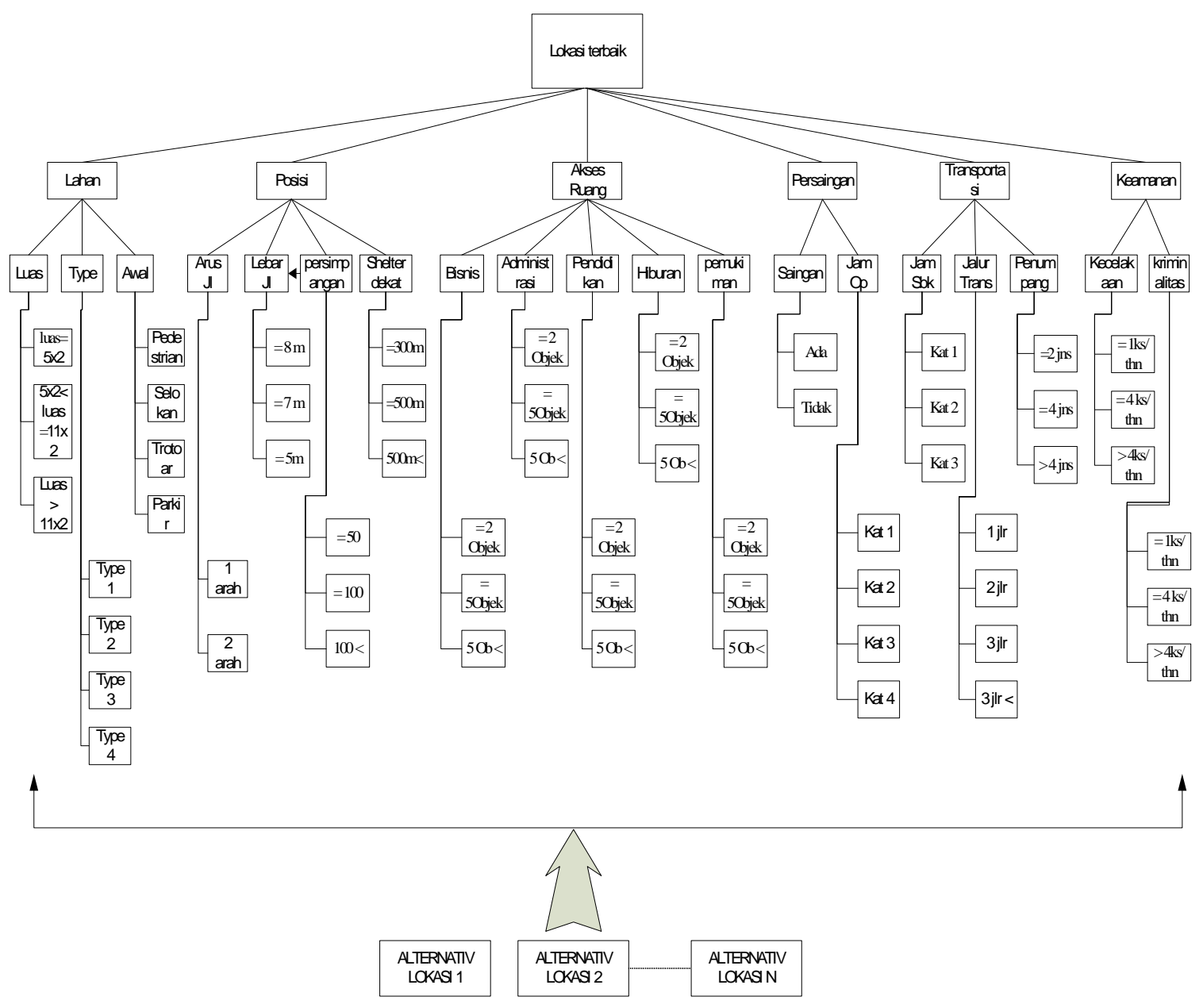

Gambar 2. Hirarki Penentuan Lokasi Shelter

Pengukuran performanis faktor subyektif menggunakan persamaan:

$S F i=\sum\left(S F W_{j}: S W_{i j}\right)$

Dimana:

$\mathrm{SF}_{\mathrm{i}}=$ Subjective Factor;

$\mathrm{SFW}_{\mathrm{j}}=$ bobot kriteria;

$\mathrm{SW}_{\mathrm{ij}}=$ rating lokasi didalam kriteria. 
Setelah OF dan SF diidentifikasi maka dapat dilakukan perhitungan LPM dengan persamaan:

$\mathrm{LPM}=(\alpha \times \mathrm{OF})+((1-\alpha) \times \mathrm{SF})$

\subsubsection{Borda}

Perhitungan tingkat kelompok digunakan metode borda sebagai metode voting untuk menentukan lokasi terbaik berdasarkan preferensi kelompok DM. Output proses perhitungan LPM berupa alternatif lokasi teranking menjadi input proses Borda. Alternatif lokasi diberikan poin N-1 untuk setiap tingkatan ranking. Poin terbesar diperoleh alternatif lokasi dengan ranking teratas paling banyak dari kelompok DM.

\subsection{Diagram Alir Data}

Data flow diagram digunakan untuk menyajikan sebuah sistem atau perangkat lunak pada setiap abstraksi dan dapat dibagi kedalam tingkat-tingkat yang merepresentasikan aliran informasi yang bertambah. Data flow diagram memberikan suatu mekanisme bagi pemodelan fungsional dan pemodelan aliran informasi. Data flow diagram level satu Group Decision Support System untuk menetukan lokasi shelter baru bus Transjogja dapat dilihat pada Gambar 2. Pada Gambar 3 DFD level 1 menunjukan ada 8 proses yaitu: login, input data, AHP, perhitungan faktor obyektif, perhitungan faktor subyektif, perhitungan LPM dan Borda, Laporan DM, Laporan administrator.

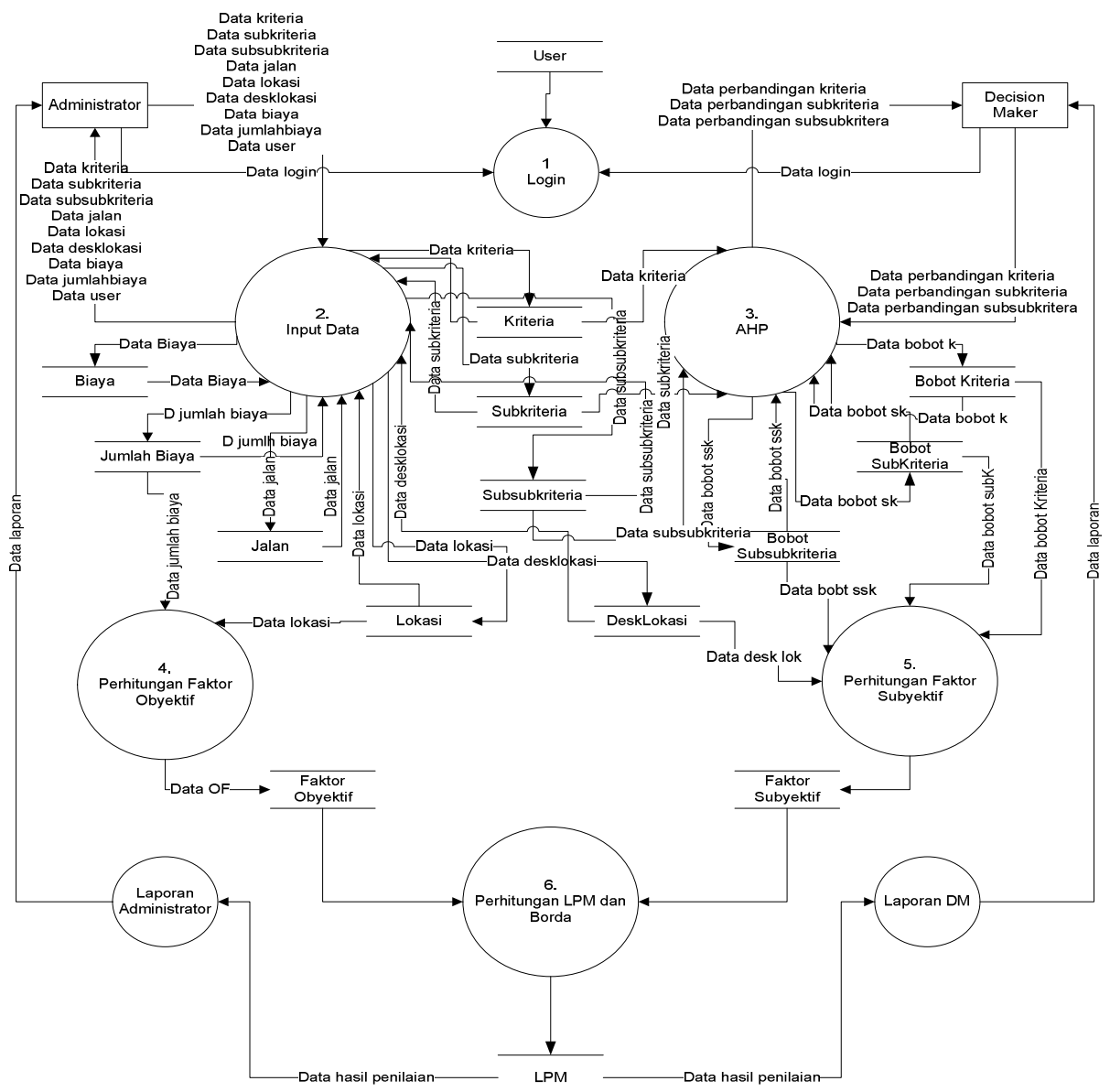

Gambar 3. DFD Level 1 GDSS Penentuan Lokasi Shelter Baru 


\subsection{Implementasi Sistem}

Setelah proses perancangan sistem dilakukan, tahap selanjutnya adalah membuat implementasi Group Decision Support System untuk untuk menetukan lokasi shelter baru bus Transjogja. bahasa pemerograman HTML, PHP, dan Javascript untuk antarmuka pengguna dan MySQL untuk perancangan basis data dengan sistem operasi Windows 7. Perangkat keras yang digunakan adalah komputer dengan spesifikasi posesor intel dualcore (2500Mhz), memory 2 GB DDR 2, dan Hardisk Sata 160 GB. Browser yang dianjurkan dalam mengakses situs adalah Mozila firefox 4 atau yang terbaru.

Dalam proses penilaian alternatif lokasi administrator perlu memasukan data jumlah biaya dan data deskripsi lokasi sebagai view dari DSS. Kemudian DM memberikan penilaian dengan menginputkan nilai perbandingan tingkat kepentingan pada kriteria, subkriteria, dan subsubkriteria. Setelah para DM memberikan inputan penilaian sistem akan mengolah masukan berupa deskripsi lokasi dan pembobotan oleh DM untuk proses penilaian faktor subyektif(SF) dan data jumlah biaya untuk penilaian faktor obyektif(OF). Dari faktor obyektif dan subyektif yang diketahui dilakukan perhitungan Location Preference Measuremen (LPM) sehingga didapat keluaran berupa data SF,OF,LPM dan Rangking alternatif dalam satu ruas jalan seperti ditunjukan pada Gambar 4.

..:: Location Preference Measurement ::..

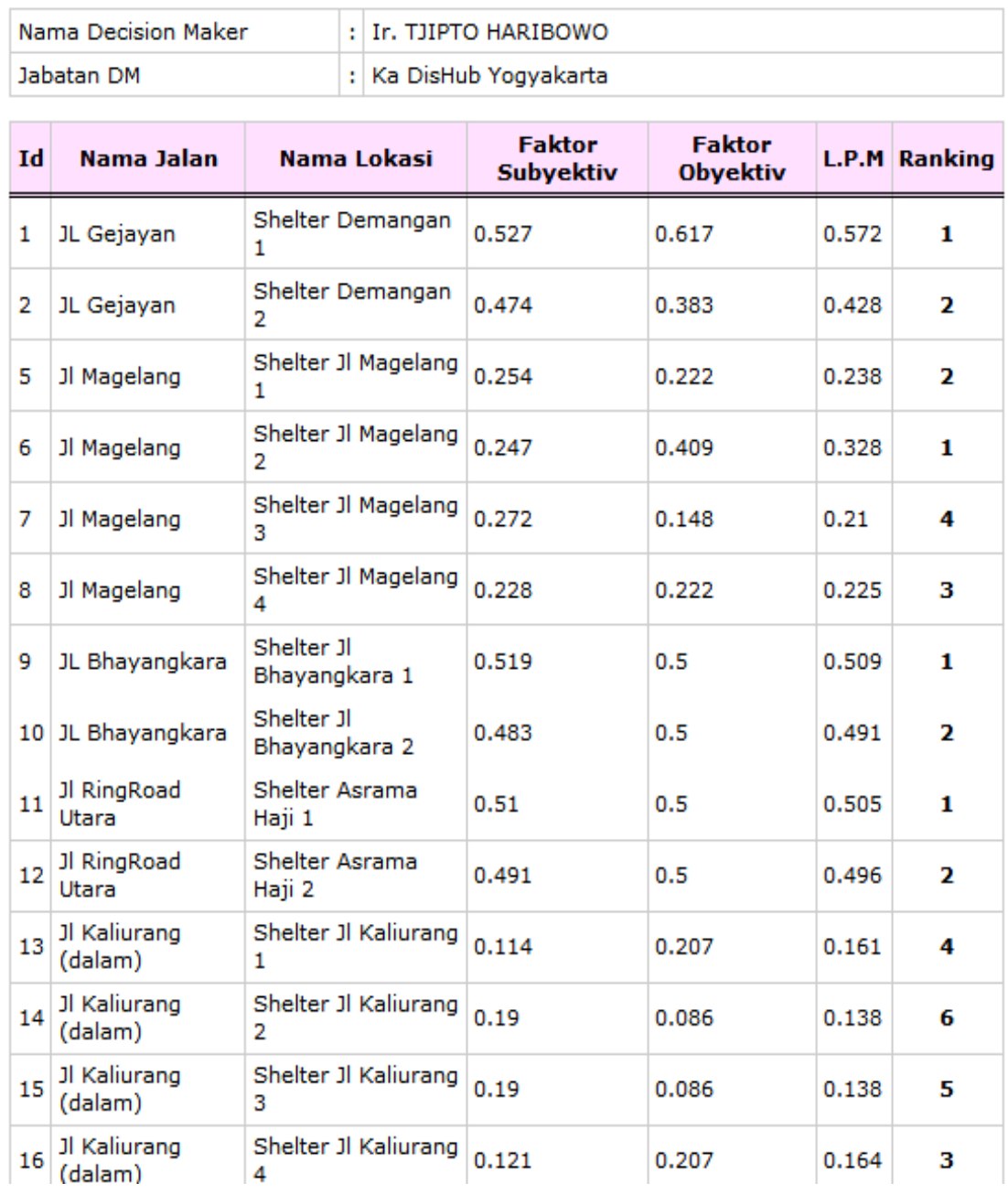

Gambar 4. Output penilaian LPM oleh DM 
Output penilaian LPM oleh DM berupa ranking lokasi merupakan input bagi proses perhitungan borda. Alternatif lokasi dengan perolehan ranking tertinggi terbanyak dari para DM merupakan lokasi dengan prioritas terbesar untuk dipilih. Gambar 4 menunjukan hasil perhitungan borda oleh kelompok.

\section{Perhitungan Borda}

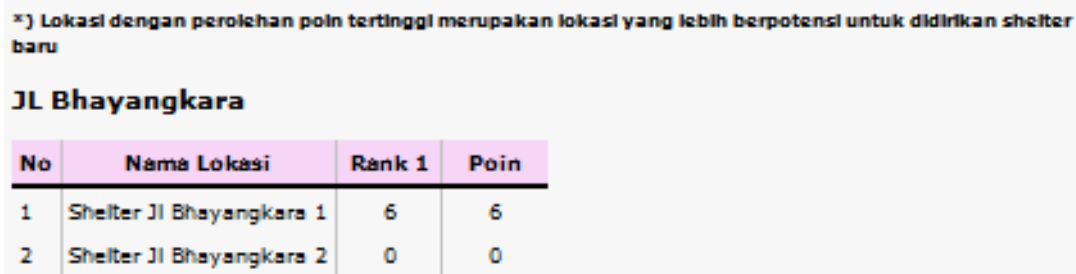

JL Gejayan

\begin{tabular}{l|c|c|c}
\hline No & Nama Lokasi & Rank 1 & Poin \\
\hline 1 & Shelter Demangan 1 & 6 & 6 \\
\hline 2 & Shelter Demangan 2 & 0 & 0
\end{tabular}

Jl Kaliurang (dalam)

\begin{tabular}{|c|c|c|c|c|c|c|c|}
\hline No & Nama Lolcasi & Rank 1 & Rank 2 & Rank 3 & Rank 4 & Rank 5 & Poin \\
\hline 1 & Shelter Jl Kaliurang 1 & 0 & 0 & 0 & 6 & 0 & 12 \\
\hline 2 & Shalter Jl Kaliurang 2 & 0 & 0 & 0 & 0 & 1 & 1 \\
\hline 3 & Shelter Jl Kaliurang 3 & 0 & 0 & 0 & 0 & 5 & 5 \\
\hline 4 & Shelter Jl Kaliurang 4 & 0 & 0 & 6 & 0 & 0 & 18 \\
\hline 5 & Shelter Jl Kaliurang 5 & 4 & 2 & 0 & 0 & 0 & 28 \\
\hline 6 & Shelter Jl Kaliurang 6 & 2 & 4 & 0 & 0 & 0 & 26 \\
\hline
\end{tabular}

Jl Magelang

\begin{tabular}{l|c|c|ccc|} 
No & Narma Lokasi & Rank 1 & Rank 2 & Rank 3 & Poin \\
\hline 1 & Shelter Jl Magelang 1 & 0 & 5 & 1 & 11 \\
2 & Shelter Jl Magelang 2 & 6 & 0 & 0 & 18 \\
\hline 3 & Shelter Jl Magelang 3 & 0 & 0 & 0 & 0 \\
\hline 4 & Shelter Jl Magelang 4 & 0 & 1 & 5 & 7
\end{tabular}

Gambar 5. Perhitungan Borda oleh kelompok.

\section{HASIL PEMBAHASAN}

Pengujian dilakukan terhadap beberapa alternatif lokasi pada beberapa ruas jalan dengan kriteria yang berbeda yaitu 10 alternatif lokasi pada 4 ruas jalan. Pemberian perbedaan harga shelter dan perbedan inputan tingkat kepentingan oleh para DM sangat mempengaruhi nilai LPM yang didapatkan oleh lokasi. Shelter dengan total biaya terbesar dari kumpulan shelter akan mendapatkan nilai faktor obyektif terkecil. Perhitungan subyektif faktor dengan menggunakan AHP memungkinkan pembobotan pada masing-masing DM berbeda sesuai dengan presepsi kepentingan kriteria, subkriteria dan subsubkriteria. LPM oleh para DM akan memiliki nilai teringgi bilamana shelter tersebut memiliki total harga termurah dan kriteria sesuai dengan presepsi DM. 
Kemudian Validasi dilakukan untuk mengetahui apakah model, sebagai konseptualisasi atau abstraksi, merupakan representasi berarti dan akurat dari sistem nyata. Masalah validasi sistem komputer adalah apakah output model komputer mempunyai kredibilitas dengan ahli sistem dan para pembuat keputusan. Pada penelitian ini untuk mengetahui validitas model yang dibuat dengan membandingkan output simulasi aplikasi dengan sistem nyata. Data histori pemilihan lokasi shelter yang pernah dilakukan oleh dinas Perhubungan

\section{KESIMPULAN}

Kesimpulan yang didapat dari hasil penelitian dengan judul Aplikasi Group Decision Support System Untuk Menentukan Lokasi Shelter Baru Bus Transjogja Menggunakan Metode Brown Gibson dan Borda adalah:

1. Penentuan lokasi shelter baru bus transjogja yang melibatkan banyak pengambil keputusan dapat dilakukan dengan menggunakan GDSS dengan metode Brown-Gibson, banyaknya preferensi terhadap alternatif lokasi dapat akomodasi dengan menggunakan metode Borda.

2. Keluaran dari sistem adalah rekomendasi alternatif lokasi dengan perankingan LPM pada DM dan poin terbesar pada putusan kelompok.

3. Penambahan kriteria, subkriteria, dan subsubkriteria untuk penilaian preferensi lokasi dapat dilakukan sehingga sistem ini bersifat dinamis disesuaikan dengan kebutuhan pengambil keputusan.

\section{SARAN}

Penelitian ini menggunakan Brown-Gibson memiliki kelemahan yaitu pengukuran performansi faktor obyektif hanya ditentukan dari cost atau biaya total yang dikeluarkan. Penulis menyarankan untuk penelitian berikutnya dapat digunakan extended Brown-Gibson dimana pengukuran performansi faktor obyektif yaitu dengan mengetahui efektifitas biaya dan waktu. Sehingga memungkinkan penilaian LPM lebih optimal.

\section{UCAPAN TERIMA KASIH}

Segala puji bagi Allah yang telah memberikan karunia bagi penulis sehingga dapat menyelesaikan penelitian ini. Terima kasih juga penulis ucapkan kepada semua pihak atas dukungan nya.

\section{DAFTAR PUSTAKA}

[1] Brown, P. A., and Gibson D. F., (1972). A Quantified Model for Facility Site SelectionApplication to a Multiplant Location Problem, IIE Transanctions, Vol. 4

[2] Miarsa,SC.,2007, Penentuan Lokasi Pabrik Kertas Paperline dengan menggunakan Metode Brown Gibson,Tesis, Program Magister Teknik Elektro, Sekolah Pasca Sarjana Universitas Gadjah Mada, Yogyakarta.

[3] Tarida,E.,2007, Penentuan Lokasi Cabang Baru berdasarkan Metode Brown Gibson(Studi Kasus: Lembaga Bahasa Inggris ILP,Jakarta),Tesis,Universitas Gadjah Mada, Yogyakarta. 
[4] Wahyuni,2003, Analisa Pemilihan Lokasi Garasi Bus dengan Metode Brown Gibson pada Perusahaan Jasa Angkutan PO. Akas Jawa Timur,Tesis, Magister Ekonomi Universitas Muhammadiyah Malang, Malang

[5] Ismawati, N.,2010, Sistem pendukung keputusan pemilihan lokasi menggunakan methode Brown Gibson (Studi Kasus: Lembaga Bimbingan Belajar Nurul Fikri, Jakarta).Tesis. Program Magister Ilmu Komputer, Sekolah Pasca Sarjana Universitas Gadjah Mada, Yogyakarta.

[6] Mekuria, M., C.,2009, Bus stop spacing optimization on a realistic street network, Desertasi,Irish northeastern University, Boston, Massachusetts. 